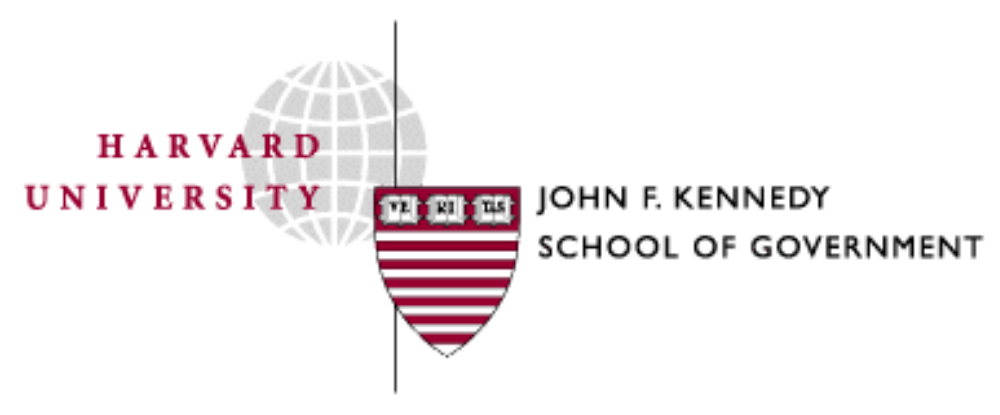

Faculty Research Working Papers Series

The Mistaken Assumption of Intentionality in Equal Protection Law: Psychological Science and the Interpretation of the Fourteenth Amendment

Margaret Richardson and Todd L. Pittinsky

February 2005

RWP05-011

The views expressed in the KSG Faculty Research Working Paper Series are those of the author(s) and do not necessarily reflect those of the John F. Kennedy School of Government or Harvard University. Copyright belongs to the author(s). Papers may be downloaded for personal use only. 
The Mistaken Assumption of Intentionality in Equal Protection Law: Psychological Science and the Interpretation of the Fourteenth Amendment

\author{
Margaret Richardson \\ University of California, Berkeley \\ Todd L. Pittinsky \\ Harvard University
}

Keywords: intentionality, equal protection law, psychological science

Correspondence should please be directed to:

Todd L. Pittinsky

John F. Kennedy School of Government

Harvard University

79 J.F.K. Street

Cambridge, Massachusetts 02138

todd_pittinsky@harvard.edu 


\section{The Mistaken Assumption of Intentionality in Equal Protection Law: Psychological Science and the Interpretation of the Fourteenth Amendment}

\section{Introduction}

The Constitution guarantees, under the Equal Protection clause of the Fourteenth Amendment, that the government must treat a person or class of persons the same way that it treats other persons or classes in like circumstances. ${ }^{1}$ Contemporary constitutional interpretations have found this to mean that a law that distinguishes on the basis of race, among other things, must have a legally justifiable basis for doing so. These parameters, on first examination, seem straightforward enough. This simplicity, however, belies the complex history of this law and its application to contemporary discrimination cases. The Fourteenth Amendment was written and ratified at the end of the U.S. Civil War to protect African Americans from the racial discrimination that accompanied the end of slavery. ${ }^{2}$ The Equal Protection clause was intended as both a sword and a shield for racial equality. As a sword, it was intended to disassemble racially discriminatory laws and official policies that had persisted from the nation's founding through the Civil War. As a shield, it was intended to protect against future laws and policies that might discriminate against African Americans on the basis of race and other suspect classifications. ${ }^{3}$

\footnotetext{
${ }^{1}$ U.S. Const. amend. XIV; BLACK’s LAW DiCTIONARY 441 (7th ed. 2000).

${ }^{2}$ See generally Coleman v. Miller, 307 U.S. 433, 448 (1939) (describing the resistance of some Southern state legislatures to the Thirteenth and Fourteenth Amendments).

${ }^{3}$ Miller v. Johnson, 115 S. Ct. 2475, 2497 (1995) (acknowledging that "the driving force behind the adoption of the Fourteenth Amendment was the desire to end legal discrimination against blacks”); Strauder v. West Virginia, 100 U.S. 303, 310 (1879) (describing that "its [the Fourteenth Amendment's] aim was against discrimination because of race or color").
} 
However, the ideal of Equal Protection — that all classes of people experience the laws identically—has never been realized. In the last three decades, Equal Protection jurisprudence has evolved from a means of remedying historic and contemporary racial discrimination into a standard that all but prevents official consideration of racial categories. The Supreme Court carried out this conversion through holdings on legal challenges to racially discriminatory policies and on official efforts to remedy existing discrimination, holdings which showed its unwillingness to consider historic and contemporary contexts in the consideration of laws. In other words, both the sword and the shield aspects of the legislative intent behind the Fourteenth Amendment have been largely abandoned. ${ }^{4}$

Social science findings have figured prominently in jurisprudence and legislation pertaining to discrimination and prejudice, both as trial evidence and as the theoretical foundation on which law has been built. The Court's choice to construe Equal Protection precedent as applicable to laws that are meant both to aid and to injure racial minorities is inspired, in part, by its attachment to the psychological assumptions that discrimination results from malicious, intentional, and controllable behavior. Yet these assumptions are outdated; they have been consistently challenged by social science for several decades and have been compellingly, verifiably, and reliably contradicted by recent findings. ${ }^{5}$ Thus, a conspicuous and compelling disconnect exists for legal inquiry.

Although social science once shared the Court's understanding of discrimination, it has more recently come to question the volitional natures of prejudice and discrimination. ${ }^{6}$

\footnotetext{
${ }^{4}$ See generally Washington v. Davis, 426 U.S. 229 (1976); Adarand v. Pena, 515 U.S. 200 (1995).

${ }^{5}$ See generally Mahzarin R. Banaji, Ordinary Prejudices, Psychological SCIENCE AGENDA, 8 (Jan./Feb. 2001); Allen R. McConnell and Jill M. Leibold, Relations Between the Implicit Association Test, Discriminatory Behavior and Explicit Measures of Racial Attitudes, 37 Journal of Experimental Social Psychology, 435, 435 (2001)

${ }^{6}$ Anthony G. Greenwald and Mahzarin R. Banaji, Implicit Social Cognition: Attitudes, Self-Esteem and Stereotypes, Psychological Review, Vol. 102, No. 1, 4, 4 (1995). In this paper prejudice signifies adverse judgments, opinions,
} 
Significant research has consistently and effectively demonstrated that attitudes about racial groups and stereotypes about members of these groups are often unconscious and operate at an implicit level. ${ }^{7}$

Research into implicit attitudes, using the Implicit Association Test (IAT), looking at "actions or judgments that are under the control of automatically activated evaluation, without the performer's awareness of that causation," ${ }^{8}$ has been useful in demonstrating several implicit biases that subjects do not profess to hold, particularly implicit racial and ethnic biases. ${ }^{9}$ First, individuals strongly prefer members of their own groups. However, the strength of these preferences is mediated by the degree to which each group is valued by the larger society. ${ }^{10}$ This theory predicts that when White people are valued more than people of color, people of color treat other people of color less preferentially than White people treat other White people.

Second, information and knowledge about various groups is "automatically activated," in both group members and nonmembers, by visual and verbal cues. ${ }^{11}$ Research findings on the automatic activation of information about members of stereotyped social groups in interactions undermine the assumptions of Equal Protection jurisprudence that discrimination and prejudice are assumed absent unless definitively proven to have motivated the actions of the parties in question.

suspicions or hatred of a particular group. By contrast, we define discrimination as the conference or denial of privileges and the resulting material consequences of membership in a particular group. This article primarily addresses prejudice and discrimination based on race although these questions are relevant to issues of gender, sexual orientation, age, religious and other forms of discrimination. See generally Brief Amicus Curiae of the American Psychological Association in Support of the Respondents, Grutter v. Bollinger and Gratz v. Bollinger, 539 U.S. 306 and 539 U.S. 244 (2003) (No. 02-241 \& No. 02-516).

${ }^{7}$ Id.

${ }^{8}$ Id. at 1464.

${ }^{9}$ Anthony G. Greenwald, Debbie M. McGhee and Jordan L. K. Schwartz, Measuring Individual Differences in Implicit Cognition: The Implicit Association Test, 74 Journal of Personality and Social Psychology 1478 (1998).

${ }_{11}^{10}$ Banaji, Ordinary Prejudices, at 9.

${ }^{11} I d$. 
Third, and most controversially from the legal perspective, social scientists have documented "full dissociations" between the explicit beliefs that individuals profess to hold and the implicit attitudes they hold. ${ }^{12}$ Thus, as a group, White people may report positive feelings toward Black people while demonstrating negative implicit attitudes.

All of this research undermines the common conception of discrimination on which Equal Protection jurisprudence has been based. And while some legal scholars have attempted to apply the lessons from social psychology to employment discrimination, ${ }^{13}$ the same efforts have not been made with respect to Fourteenth Amendment and Equal Protection jurisprudence. Examining this disconnect leads to serious questions about the extent to which the current formulation of Equal Protection jurisprudence achieves its original and continuing aims of securing the equal protection of the laws for all citizens. In this article, we focus on the implications for Equal Protection jurisprudence of recent psychological science findings on prejudice and discrimination. We have chosen this focus because these implications could influence the protection of individual rights throughout society in fundamental ways.

We begin, in Section II, by reviewing the theories of prejudice and discrimination articulated in seminal Equal Protection cases, then turn in Section III to Washington v. Davis. African American applicants who were denied employment with the Washington, D.C. police department claimed that the department's hiring process was discriminatory. The Supreme Court rejected their claims despite evidence of disparately high rejection of African American applicants. This case illustrates the Court's requirement that discrimination complaints be supported by proof of intent to discriminate. We next examine McCleskey v. Kemp, which

\footnotetext{
${ }^{12}$ John F. Dovidio, Samuel L. Gaertner and Kerry Kamakami, Implicit and Explicit Prejudice and Interracial Interaction, 82 Journal of Personality and Social Psychology 62, 62 (2002).

${ }^{13}$ See generally, Linda Hamilton Krieger, The Content Of Our Categories: A Cognitive Bias Approach To Discrimination And Equal Employment Opportunity, 47 STAN. L. REV. 1161 (1995).
} 
denied a request to set aside a death sentence based on evidence of the disproportionate imposition of death sentences on African Americans. McCleskey v. Kemp illustrates the Supreme Court's demand that discriminatory intent must be proven in the specific instance rather than inferred from statistical information demonstrating disparate impact on different racial groups.

These cases were nails in the coffin of the disparate impact standard in Equal Protection jurisprudence. ${ }^{14,15}$ We describe the Court's holdings and the assumptions about the nature of discrimination that each of these holdings reveal.

In section IV, we review Adarand v. Pena and Croson v. City of Richmond, two rulings which respectively outlaw federal and state government efforts to remedy disparities in the distribution of business contracts in the construction industry. These cases demonstrate the Court's unwillingness to consider beneficent intent in evaluating programs that are intended to support the economic achievement and advancement of racial minorities through classifications based on race. These holdings demonstrate the Court's tendency to justify the maintenance of the status quo, in accordance with the psychological theory of system justification. They also reveal that concern about the use of racial classifications has eclipsed concern about racial inequality. This shift in focus—a shift from creating practical equality to requiring formal equality—characterizes the Court’s most recent jurisprudence.

Finally, we turn to Gratz v. Bollinger, which struck down the University of Michigan’s undergraduate affirmative action admissions program as too close to a quota, and Grutter v. Bollinger, which upheld a more holistic approach to ensuring racial diversity in admissions at the

\footnotetext{
${ }^{14}$ Washington v. Davis, 426 US 229 (1976); McCleskey v. Kemp, 481 U.S. 279 (1987).

${ }^{15}$ Such a standard would enable plaintiffs alleging equal protection violations to prove their case using evidence of a disparate impact on a specific category or class of people, rather than through proof of a defendant's intent to discriminate. Under such an analysis, the question is whether the government or a governmental official injured an individual or a group because of a forbidden reason like racial animus. The Court was not looking into people's minds, rather it looked at their behavior. If the behavior was tied to race, religion or other "suspect" categories it was not permissible.
} 
same university’s law school. ${ }^{16}$ These cases reveal the Court's ambivalence about the use of racial classifications in education and are the Court's most recent articulations of the legality of affirmative action programs in higher education.

These cases subject the government's racial classification to the most stringent standard of review: strict scrutiny. ${ }^{17}$ By applying this standard, the Court reveals its collective assumption that differential treatment is determined by explicit distinctions rather than by internalized beliefs and attitudes that are ubiquitous and potentially unconscious and uncontrollable. Again, this requirement reveals the emphasis on formal over practical equality. Moreover, these cases most recently and clearly illustrate the divide between social science and the law.

In Section $\mathrm{V}$, we review the recent psychological findings that many attitudes about race are implicit, uncontrollable, and collectively held, despite explicit attitudes to contrary. We then examine the disconnect, the places where this new social science suggests new ways to construct a legal understanding of discrimination, with arguments that would support this effortIn section VI, we begin to examine the broader issue of how the law might better incorporate social science, specifically psychological research, as scientific findings evolve and render earlier legal understandings obsolete.

Our conclusions are presented in Section VII. It remains essential that social science findings be applied to the constitutional guarantees of Equal Protection because these are the most basic guarantees of protection from governmental discrimination. To the extent that these efforts are neglected, we will have given up on the Constitution's promise. Constitutional interpretation, like all jurisprudence, relies on the doctrine of stare decisis, Latin for "to stand by that which is decided," to ensure that prior decisions are followed by the courts as precedent.

\footnotetext{
${ }^{16}$ Grutter v. Bollinger; 539 U.S. 306 (2003); Gratz v. Bollinger, 539 U.S. 244 (2003).

${ }^{17}$ Strict scrutiny requires a governmental defendant to prove that a policy is narrowly tailored to meet a compelling governmental interest. If the defendant cannot so prove, the policy must be invalidated.
} 
Shifts in extralegal understanding of human behavior have several times provided the compelling justification required to abandon prior decisions. ${ }^{18}$ The social science that we describe provides another such compelling justification.

\section{Historical Legal Understanding of Discrimination}

In this section, we explore how discrimination has been conceptualized and addressed by the U.S. government and its laws, in order to see how social science might influence contemporary understandings thereof.

Even in 1784, Thomas Jefferson anticipated that "deep rooted prejudices entertained by the Whites; ten thousand recollections, by the Blacks, of the injuries they have sustained; new provocations; the real distinctions which nature has made; and many other circumstances, will divide us into parties, and produce convulsions which will probably never end but in the extermination of the one or the other race."19 Racial fear and suspicion continued to characterize the approach of lawmakers throughout the nation's first century. Under the U.S. Constitution, voting and taxation were apportioned based on the total number of "free persons." Enslaved people were counted as three-fifths of a person, however, in determining the tax obligations and the allocation of elected representatives. ${ }^{20}$ This constitutional provision defined political, civil, and social rights for African Americans until after the U.S. Civil War.

Following the Civil War, Congress debated and ultimately passed the Thirteenth, Fourteenth, and Fifteenth Amendments. These repealed the most egregious manifestations of racial discrimination—slavery, race-exclusive citizenship, and racial prohibitions on the right to

\footnotetext{
${ }^{18}$ Most famously and of most relevance, Brown v. Board of Education 347 U.S. 483 (1954) reversed the Supreme Court's holding that upheld racial segregation in Plessy v. Ferguson 163 US 537 (1896).

${ }^{19}$ Thomas Jefferson, Notes on the State of Virginia, Query XIV, in RACE AND RACES: CASES AND RESOURCES FOR A Diverse America 100 (Juan F. Perea, Richard Delgado, Angela P. Harris and Stephanie M. Wildman eds., 2000).

${ }^{20}$ U.S. CONST. art. I, § 2.
} 
vote- and charged Congress with the responsibility of enforcing these provisions through the enactment of additional laws. ${ }^{21}$ (Lincoln's Emancipation Proclamation of 1863, widely remembered as having ended slavery, in fact abolished it only in the states of the Confederacy. ${ }^{22}$ Not until the passage and ratification of the Thirteenth Amendment in 1865 did the United States formally abandon slavery.)

The Fourteenth Amendment provided the most explicit protection for rights regardless of race. ${ }^{23}$ It was an explicit attempt to overrule the Dred Scott holding that African Americans could not be citizens under the Constitution and therefore possessed none of the attendant rights and privileges. ${ }^{24}$ Section Five was added to provide Congressional authority to enforce this new provision of rights. "The amendment was undoubtedly designed to grant Congress the power to legislate on the broad view of the reach of the Thirteenth Amendment, i.e. go beyond slavery into the realm of equal rights and Equal Protection., ${ }^{25}$

Together, these constitutional amendments were meant to provide a federal baseline of protection against civil and political discrimination against African Americans; they are the first constitutional effort to uproot discrimination. But the political will to continue this effort dissipated and its intention was not fully realized. Southern states enacted the Black Codes, ${ }^{26}$ mandating and maintaining racial distinctions in access to public education, accommodations,

\footnotetext{
${ }^{21}$ U.S. ConST. amend. XIII, § 1; U.S. CONST. amend. XIV, § 1; U.S. CONST. amend. XV.

${ }^{22}$ Carl E. Brody, Jr., A Historical Review of Affirmative Action and The Interpretation Of Its Legislative Intent By The Supreme Court, 29 Akron L. Rev. 291, 293 (1996).

23 "All persons born or naturalized in the United States, and subject to the jurisdiction thereof, are citizens of the United States and of the State wherein they reside. No State shall make or enforce any law which shall abridge the privileges or immunities of citizens of the United States; nor shall any State deprive any person of life, liberty, or property, without due process of law; nor deny to any person within its jurisdiction the equal protection of the laws. The Congress shall have power to enforce, by appropriate legislation, the provisions of this article.” U.S. CONST. amend. XIV, § 1; Id. § 5.

${ }^{24}$ Scott v. Sanford, 60 U.S. 393, 406 (1956).

${ }^{25}$ Jack M. Beerman, The Unhappy History of Civil Rights Legislation, Fifty Years Later, 34 Conn. L. Rev. 981, 984 (2002).

${ }^{26}$ Christopher P. Banks, The Constitutional Politics of Interpreting Section 5 of the Fourteenth Amendment, 36 Akron L. Rev. 425, 432 (2003).
} 
and transportation. Thus, many states, with the tacit consent of the non-intervening federal government, explicitly authorized discrimination through segregation. In Plessy v. Ferguson, the Supreme Court affirmed that distinctions based on race were permissible under both the Thirteenth and Fourteenth Amendments. ${ }^{27}$ This holding introduced the legal doctrine of “separate but equal," upholding segregation so long as laws did not mandate inferior facilities for African Americans. This doctrine became synonymous with government endorsement of discrimination and became the target of civil rights attorneys striving to realize racial equality. ${ }^{28}$

After several decades and a meticulously planned legal strategy by the NAACP, the Court reversed its Plessy holding in Brown v. Board of Education. ${ }^{29}$ In preparation for the litigation, NAACP attorneys worked with social scientists to document the negative psychological impacts of segregation on African American children and the ways in which these feelings undermined their ability to learn. ${ }^{30}$ The demonstrated impact of segregation on the psyches of children in segregated schools was clear and convincing and supported the commonsense understanding that segregation was based on the belief, and reinforced a message of, White racial superiority.

Citing this impact, the Court held that segregation in public education deprived minority children of an "equal educational opportunity."31 (To avoid the obvious impediment of the Court's earlier sanction of segregation as compliant with the Fourteenth Amendment and the Equal Protection clause, the Court found the legislative intent and history of the amendment

\footnotetext{
${ }^{27} 163$ US 537, 550-551 (1896).

${ }^{28} \mathrm{Id}$.

${ }^{29} 347$ US 483, 494 (1954).

${ }^{30}$ Id. at 494.

${ }^{31}$ Id. at 493.
} 
“inconclusive., ${ }^{32}$ ) Although specific psychological findings were referenced only in a footnote, ${ }^{33}$ the unanimous Court accepted as persuasive the psychological evidence that:

Segregation of white and colored children in public schools has a detrimental effect upon the colored children. The impact is greater when it has the sanction of the law, for the policy of separating the races is usually interpreted as denoting the inferiority of the Negro group. A sense of inferiority affects the motivation of a child to learn. Segregation with the sanction of law, therefore, has a tendency to [retard] the educational and mental development of Negro children and to deprive them of some of the benefits they would receive in a racial[ly] integrated school system. ${ }^{34}$

The power of the psychological findings bolstered the political and jurisprudential judgment that separate was inherently unequal. The Brown decision rearticulated the Equal Protection clause of the Fourteenth Amendment as protecting a racial group's rights from being harmed by laws with discriminatory impact. But more enduringly, Brown enshrined judicial suspicion of official classifications based on race. This suspicion has ultimately restricted the philosophical basis of Equal Protection jurisprudence, undermining its ability to ensure equal outcomes.

The Court and legal community more generally have, to varying degrees since Brown v. Board of Education, seen the law as a tool to enforce equality. While it is commonly agreed that the "separate but equal" policies prevalent in the early twentieth century were unequal, legal advocates and academics have been divided over how equality might effectively be protected and enforced. Some assert that Equal Protection requires formal and procedural equality, while others assert that the law should ensure practical equality. Procedural equality would ensure that all groups and individuals would experience policies and laws similarly, while practical equality would ensure that policies and laws were used to achieve equality. Underlying each of these

\footnotetext{
${ }^{32}$ Id. at 489.

${ }^{33}$ Id. footnote 11 .

${ }^{34}$ Id. (citing K. B. Clark, Effect of Prejudice and Discrimination on Personality Development, Midcentury White House Conference on Children and Youth, 1950).
} 
beliefs is a substantively different understanding of the ways in which the government should operate to correct socially significant racial disparities.

While the Fourteenth Amendment was originally used to dismantle the segregationist laws that had plagued the nation through most of its history, it has more recently been invoked as the basis for undermining laws and policies intended to dismantle the legacy of the segregationist regime and commonsense. At the time of its articulation, those who drafted and ratified the Fourteenth Amendment could not have known that it would come to be used as a shield against challenges to racially disparate effects of laws and government policies and as a sword against policies that attempt to alleviate existing racial inequities. These inversions have in part been the result of the legislative and jurisprudential common conception of racial discrimination as resulting from bad actions or bad policies enacted by bad people. The corollary of this supposition is that without malicious intent there is no remediable discrimination. ${ }^{35}$

\section{Development of the Discriminatory Intent Requirement}

In the years following the Brown decision, it had become self-evident that discrimination operated at many social levels. Surprisingly, as society became less tolerant of discrimination, the Court raised the bar on proving that a government agency, policy, or officer had discriminated on the basis of race. In Washington v. Davis, the Court first rejected the possibility that disparate impact on different communities could suffice as a prima facie violation of the Equal Protection clause. Then, in McCleskey v. Kemp, the Court imposed the requirement that claimants demonstrate up to a moral certainty that discrimination had been outcomedeterminative in their individual case. The Court thus moved away from the discriminatory impact standard to the discriminatory intent requirement. These holdings have articulated and

\footnotetext{
${ }^{35}$ Washington, 426 U.S. at 245.
} 
ensconced the principle that laws and official actions, even those that have demonstrably disparate results, are only in violation of the Equal Protection clause of the Fourteenth Amendment when they manifest intent to discriminate and when this intention led to the enactment of the law. This understanding of the Equal Protection clause parallels the understanding amongst twentieth century social scientists that prejudice and discrimination are volitional, conscious, and, as a result, controllable and containable.

\section{A. Washington v. Davis}

In the early 1970s, following the end of de jure segregation in Washington D.C.'s administrative services and police force, the municipal government instituted a written exam called Test 21, race-neutral in its design and administered to all applicants regardless of race. ${ }^{36}$ In Washington v. Davis, African American applicants for positions as Washington, D.C. police officers sued the city after failing to be hired, claiming that the hiring process, particularly Test 21, illegally discriminated against racial minorities. The applicants argued that, as Test 21 not only was unrelated to job performance but also disproportionately excluded Black applicants, it violated both constitutional and statutory principles of Equal Protection. The claimants did not present evidence at trial as to the intent of the police department, relying on the evidence of the discriminatory impact of Test 21 to demonstrate their Equal Protection complaint. The Supreme Court hung its holding on this omission, ${ }^{37}$ finding that, barring a finding of "intentional discrimination or purposeful discriminatory acts,” there was no violation of Equal Protection. ${ }^{38}$ The facts that the test bore no relationship to job performance and that it negatively impacted

\footnotetext{
${ }^{36}$ The question of historic unequal access to education in the city's recent past was not raised in the Court's consideration of the reality that only White applicants were passing the exam. Washington v. Davis, at 229.

${ }^{37}$ Id. at 235.

${ }^{38}$ Id.
} 
African American applicants were insufficient. ${ }^{39}$ The Court found that the most compelling statements that the failed applicants were able to make were that there were disproportionately few African Americans on the police force in comparison to their representation in the general population, that more African Americans than Whites were denied employment based on Test 21, and that there was no correlation between Test 21 and job performance as an officer. ${ }^{40}$ The Court found these conclusions unpersuasive as to the existence of discrimination in violation of the Equal Protection clause.

Moreover, the Court shared the lower courts' unwillingness to accept “the assertion that Test 21 was culturally slanted to favor Whites." ${ }^{41}$ It was unwilling to find a constitutionally impermissible consequence of Test 21 and affirmed the District Court's assumption that the test improved the standards of the police department and supported their "efforts to achieve excellence.” The Court's choice of words illustrates their assumptions about the generally benevolent motives behind the police force hiring procedure and their willingness to impute benign motives to explicitly racially neutral policies. This willingness stems from the Court's assumptions that intentional malevolence is required for racial discrimination to be found unconstitutional. The Court's language also reflects the assumption that the exclusion of African Americans would not undermine the police department's efforts to achieve excellence.

Thus, the Court, in contrast to its previous assertion of the equalizing intent of the amendments, here found that the intent to prevent discrimination on the basis of race was not sufficient to invalidate laws, policies, or regulations that had disproportionate impacts. ${ }^{42}$ The Court concluded that it had "not embraced the proposition that a law or other official act, without

\footnotetext{
${ }^{39}$ Id. at 237.

${ }^{40} I d$. at 235.

${ }^{41}$ Id.

${ }^{42}$ Washington. at 239.
} 
regard to whether it reflects a racially discriminatory purpose, is unconstitutional solely because it has a racially disproportionate impact.”43 The Court went on to analogize this holding to other situations in which it had found that statistical disparities were insufficient to support a finding of unconstitutional discrimination. ${ }^{44}$

Washington v. Davis has come to represent the Court's requirement of proof of invidious motive in order to invalidate laws having a discriminatory impact on racial minorities. This standard has proven a great impediment to challenging policies and administrative procedures that disproportionately affect specific racial minorities. It places the nearly impossible burden of proof and persuasion on those who have experienced the exclusion. In a sense, it asks the victim to go into the mind of the perpetrator and demonstrate that there exists an unconstitutional motivation. ${ }^{45}$ Yet, as we will reveal in the discussion of contemporary psychological research infra, such motives may not be knowable, even to the perpetrator himself or herself, particularly when there are race-neutral explanations. ${ }^{46}$ Moreover, when there are a variety of actors involved in policy and administrative decisions, the resultant behavior can always be attributed to individuals’ racially neutral considerations and it becomes even harder for a complainant to demonstrate evidence of discriminatory intent. ${ }^{47}$

A year after Washington v. Davis, the Court confirmed its commitment to this new understanding of the meaning and potential of the Equal Protection clause in its holding in Arlington Heights v. Metropolitan Housing Development Corporation, stating: “Washington v. Davis made it clear that official action will not be held unconstitutional solely because it results

\footnotetext{
${ }^{43} I d$.

${ }^{44} I d$. at 241.

45 Charles R. Lawrence III, The Id, the Ego, and Equal Protection: Reckoning with Unconscious Racism, 39 Stan. L. Rev. 317, 319 (1987).

${ }^{46}$ John F. Dovidio and Samuel Gaertner, Aversive Racism and Selection Decisions: 1989 and 1999, 11 Psychological Science, 315, 318 (2000).

47 Lawrence supra note 51, at 320.
} 
in a racially disproportionate impact." ${ }^{48}$ This decision further asserts that plaintiffs need not prove a sole or primary purpose to discriminate, but they must be able to prove that it was "a motivating factor in the decision" that led to a disparate impact on a racial minority. ${ }^{49}$ Again, in looking at recent psychological findings, the difficulty and perhaps imprudence of such a requirement will become clear.

\section{B. McCleskey v. Kemp}

The understanding of Equal Protection articulated in Washington v. Davis was challenged approximately ten years later in McCleskey $v$. Kemp, which challenged the constitutionality of the Georgia death penalty based on its unequal imposition on African Americans.

In the preparation of the appeal, the defense for the sentenced man, McCleskey, prepared a statistical analysis of the disparities between the imposition of the death penalty in cases across a variety of factors, this analysis became known as the Baldus Report. ${ }^{50}$ This report demonstrated that the death sentences imposed by juries were more predictably based on the race of the defendant and the race of the victim than on any other of a host of factors. The defense attorneys argued that these disparate results provided evidence of the discriminatory impact of the death penalty statute. ${ }^{51}$

The majority of the Court, concerned about the implications of this case for all capital cases in Georgia and for other criminal laws imposed disparately on White and Black defendants, firmly rejected this assertion. ${ }^{52}$ Although the report meticulously presented undeniable correlations between the race of the defendant, the race of the victim, and the penalty imposed, the Court would not find an equal protection violation based on this evidence. The

\footnotetext{
${ }^{48}$ Arlington Heights v. Metro. Hous. Dev. Corp. , 429 U.S. 252 at 264-6 (1977).

${ }^{49}$ Id.

${ }^{50} I d$. at 279.

${ }^{51} \mathrm{Id}$.

${ }^{52}$ Id. at 282-283.
} 
Court specified that in this case, McCleskey would have to have had proof that the operation of discrimination had motivated the passage of the law permitting the imposition of the death penalty, that the death penalty remained legal based on invidiously discriminatory motives of the members of the legislature, and that the jury in the defendant's specific case had been similarly motivated by an invidiously discriminatory intent. In other words, McCleskey, a death row inmate in Georgia, was asked to prove that Georgia state legislators and members of the jury in his case acted with discriminatory purpose. This burden was insurmountable enough. He additionally would have been required to show that, but for this discrimination, he would not have received the death penalty for his murder conviction. ${ }^{53}$

The Court found that McCleskey had failed to meet this burden. Researchers had testified that the statistics revealed averages; the Court used their testimony in order to reject the contention that the statistics revealed what had happened in McCleskey's case. ${ }^{54}$ The court went on to assert that "each jury is unique in its composition, and the Constitution requires that its decision rest on consideration of innumerable factors that vary according to the characteristics of the individual defendant and the facts of the particular capital offense." 55 In this way, the court refused to impute invidious discriminatory attitudes to a broad segment of the population, despite the compelling social scientific evidence.

In addition to creating the legal fiction that McCleskey’s case might have been a statistical anomaly out of line with the majority of cases in the study, the Court's statement virtually excluded the possibility of future courts considering social science reports based on statistics to understand the circumstances in an individual case. The Court undermined the validity of the analysis, saying that the "study indicates a discrepancy that appears to correlate

\footnotetext{
${ }^{53} \mathrm{Id}$.

${ }^{54} \mathrm{Id}$.

${ }^{55}$ Id. at 292-295.
} 
with race. Apparent disparities in sentencing are an inevitable part of our criminal justice system." ${ }^{56}$ Finally, the Court cited Baldus’s testimony that the statistics could not ensure "to a moral certainty" that race influenced the decisions in this specific case to claim that the high probability of racism in sentencing indicated by the study was constitutionally irrelevant. ${ }^{57}$

Thus, the Court first argued that the study showed nothing that offended the constitutional protections generally, and Equal Protection more specifically. It went on to acknowledge that the appearance of disparities are inherent in the administration of American criminal law. Writing for the Court, Justice Powell described the case as the majority saw it: "McCleskey asks us to accept the likelihood allegedly shown by the Baldus study as the constitutional measure of an unacceptable risk of racial prejudice influencing capital cases. This we decline to do." ${ }^{58}$ The Court upheld McCleskey’s conviction and death sentence. ${ }^{59}$ This holding offended the dissenting Justices so much so that they described the majority's unwillingness to regard McCleskey's evidence as sufficient to prove racial discrimination as "a fear of too much justice.,

The Court further insulated the state of Georgia by rejecting the possibility that the state as a whole "acted with a discriminatory purpose." ${ }^{\text {61 }}$ It went on to reiterate its high standard for finding an unconstitutional level of intent, specifically that the decision maker select or reaffirm a particular course of action at least in part "because of," not merely “in spite of,” its discriminatory impact on a racial minority group. ${ }^{62}$ Because the Court had no evidence that the

\footnotetext{
${ }^{56} I d$. at 312.

${ }^{57}$ Id. at 297.

${ }^{58} \mathrm{Id}$. at 289.

${ }^{59} \mathrm{Id}$, at 298.

${ }^{60} I d$, at 338.

${ }^{61}$ Id. at 292.

${ }^{62}$ Id. at 297-298.
} 
Georgia legislature or the specific jury in this case acted with a discriminatory end in mind, the Court denied McCleskey’s Equal Protection claim. ${ }^{63}$

This intent standard has remained as the level of unconstitutional discrimination required to prove a constitutional violation of Equal Protection principles. The Court's imposition of this standard demonstrates its beliefs that the intent of individual and organizational actors can be isolated and that intentional beliefs — and actions based on intentional beliefs-define the scope of policies that have racially disproportionate impacts.

\section{Strict Scrutiny Analysis for Racial Classifications}

Over the past quarter of a century, the Court has increasingly come to understand racial classifications as invidious per se. ${ }^{64}$ The Court clearly does not trust state governments or the federal government to act in a benign fashion when racial categorizations are concerned. ${ }^{65}$ This has had critical consequences in the consideration of affirmative action programs.

The Supreme Court considered a law that made explicit distinctions based on race in Korematsu v. United States, which considered the constitutionality of government internment of Japanese Americans during World War II. In upholding the internment, the Court first articulated the standard of strict scrutiny, which requires the governmental defendant to demonstrate that the challenged racial classification or violation of a fundamental right is based on a compelling governmental interest and is narrowly tailored to achieve that compelling governmental interest. Applying this standard to the facts of this case, the Court held that the internment of Japanese Americans was necessary to achieve a compelling governmental

\footnotetext{
${ }^{63} \mathrm{Id}$.

${ }^{64}$ Richmond v. J. A. Croson Co., 488 U.S. 469, 493 (1989).

${ }^{65} \mathrm{Id}$.
} 
interest — national security during World War II. This was the first and only time that the Court had upheld racial classifications that burdened racial minorities, finding that the federal government's concern for national security met the "pressing public necessity standard."66 After Korematsu, however, the standard of review for racial classification in policies intended to benefit racial minorities remained unclear. ${ }^{67}$ In Regents of the University of California v. Bakke, four Justices argued for intermediate scrutiny of racial classifications designed to further remedial purposes, stating that they "must serve important governmental objectives and must be substantially related to the achievement of those objectives." ${ }^{\text {.68 }}$ Justice Powell, however, wrote that such classifications should be subject to strict scrutiny. Under that standard, remedial racial classifications would be required to address compelling governmental interests and be narrowly tailored to meet these objectives, just as discriminatory racial classifications would be. ${ }^{69}$ Although the Court struggled to determine a single standard to use with respect to policies meant to remedy racial discrimination, it did not settle on the strict scrutiny requirement until more than a decade later in the case of Croson v. City of Richmond.

\section{A. Croson v. City of Richmond}

While the Court sanctioned internment, it rejected the possibility that racial animus could ever justify governmental employment of racial classifications. ${ }^{70}$ Croson concerned the City of Richmond's affirmative action policy of designating or "setting aside" thirty percent of government contracts for minority-owned businesses. While the policy made explicit racial classifications, it did so in an attempt to remedy historical disparities in the awarding of public contracts. In analyzing the constitutionality of this policy, a majority of the Court agreed that the

\footnotetext{
${ }^{66} I d$. at 216.

${ }^{67}$ Regents of the University of California v. Bakke, 438 U.S. 265 (1978).

${ }^{68} \mathrm{Id}$. at 359.

${ }^{69} \mathrm{Id}$. at 492.

${ }^{70} \mathrm{Id}$.
} 
strict scrutiny standard should be applied. Under this standard, the Court held that Richmond had not articulated a compelling governmental interest because the legislative history did not expressly mention historic discrimination by the city of Richmond. ${ }^{71}$ Such an explicit statement seemed to be required in order for the Court to uphold such a policy. ${ }^{72}$ Even a general statement of discrimination within the industry would not satisfy the Court because "it provides no guidance for the city's legislative body to determine the precise scope of the injury it seeks to remedy and would allow race-based decision making essentially limitless in scope and duration.,73

Moreover, the Court further sought "a prima facie case of a constitutional or statutory violation" in order to justify setasides within the industry. ${ }^{74}$ "The fact that the Plan declares itself to be 'remedial' is insufficient, since the mere recitation of a 'benign' or legitimate purpose for a racial classification is entitled to little or no weight." ${ }^{75}$ In this way the Court dismissed the express intentions of the legislature as illegitimate, despite the fact that the clear purpose of the law was to benefit racial minorities. In reaching this conclusion, the Court rejected the city's statistical analysis that revealed a disparity in the awarding of city contracts to minority-owned businesses. ${ }^{, 76}$ The majority explicitly rejected the proposition that other evidence of discrimination, such as school segregation and federal reports documenting racial disparities, could have any probative value in this analysis. Furthermore, it rejected the possibility that such historical circumstances impacted the operation of the construction industry. ${ }^{77}$

\footnotetext{
${ }^{71}$ Croson, 488 U.S. at 498-506.

${ }^{72} \mathrm{Id}$.

${ }^{73} \mathrm{Id}$. at $498-499$.

${ }^{74}$ Id. at $498-499$.

${ }^{75} \mathrm{Id}$. at 500 .

${ }^{76}$ Id. at 501-504.

${ }^{77}$ Id. at 504-506.
} 
Finally, the Court's holding found the program “overinclusive,” due to the possibility that racial minorities who had not experienced historic discrimination might benefit from it. "Since there is absolutely no evidence of past discrimination against Spanish-speaking, Oriental, Indian, Eskimo, or Aleut persons in any aspect of the city's construction industry, the Plan's random inclusion of those groups strongly impugns the city's claim of remedial motivation."78 The apparent sarcasm illustrates the Court's contempt for such remedial programs in general.

Concluding that the remedy contradicted the remedial purpose of the program, ${ }^{79}$ the Court adopted a "principle of race neutrality” for evaluating programs under the Equal Protection clause. $^{80}$ Under this principle, only race-neutral programs could be vindicated by the strict scrutiny standard, under which it found the City of Richmond's program unconstitutional. ${ }^{81}$ The Court asserted in conclusion that the Fourteenth Amendment prohibits state and local governments from discriminating on the basis of race except to undo the effects of its own past discrimination. ${ }^{82}$

\section{B. Adarand v. Pena}

In Adarand v. Pena, the Court considered the standard of review for remedial actions taken by the federal government that favor a racial group. The government action in question was a United States Department of Transportation federal contract stipulating that the prime contractor would receive additional compensation if it hired small businesses controlled by "socially and economically disadvantaged individuals." The Court held that all racial classifications, whether imposed by federal, state, or local authorities, must pass strict scrutiny

\footnotetext{
${ }^{78} \mathrm{Id}$. at 506.

${ }^{79} \mathrm{Id}$. at $519-520$.

${ }^{80}$ Id at 520.

${ }^{81} \mathrm{Id}$.

${ }^{82}$ Id. at $520-525$.
} 
review. $^{83}$ In their decision, the Court clearly extended and entrenched the Croson analysis as applicable to federal programs that classify on the basis of race. The Court set forth as a standard that "all racial classifications, imposed by whatever federal, state, or local governmental actor, must be analyzed by a reviewing court under strict scrutiny.", ${ }^{\circ 4}$

To analyze the case, the Court articulated a federal Equal Protection doctrine according to three general propositions with respect to racial classifications by the federal government. The first principle was skepticism, evidenced by the requirement that all racial classifications were subject to strict scrutiny. Second, the Court attempted to ensure consistency by establishing a standard that applied to racial classifications regardless of who was helped and who was harmed. Finally, the Court attempted to establish congruence between federal and state Equal Protection standards. The Court found that "any person, of whatever race, has the right to demand that any governmental actor subject to the Constitution justify any racial classification subjecting that person to unequal treatment under the strictest judicial scrutiny.”85

The Court relied on its precedent to argue that the Fifth and Fourteenth Amendments protect persons as individuals, not as groups, despite the particular history of the Fourteenth Amendment. Thus, the Court stated that its analysis turned on the question of whether individuals had been deprived of their Equal Protection rights as a result of their group membership, not whether groups had been adversely affected in violation of Equal Protection principles. ${ }^{86}$

Just as it had in Croson, the Court applied a strict scrutiny standard, stating that federal racial classifications, like those of a State, must serve a compelling government interest and must

\footnotetext{
${ }^{83}$ Federal programs and policies were required, by the Court, to meet Equal Protection standards under the due process clause of the Fifth Amendment.

${ }^{84}$ Adarand, 515 U.S. at 227.

${ }^{85} \mathrm{Id}$. at $212-220$.

${ }^{86} I d$. at 230-231.
} 
be narrowly tailored to further that interest. ${ }^{87}$ Although the Court acknowledged the persistence of racial discrimination and its historic effects and stated that the federal government and the state governments remain able to act in response to them, the Court rejected these as compelling governmental interests per se. ${ }^{88}$ Further, the Court stated the requirement for narrowly tailored policies without identifying the parameters or giving examples of such programs. ${ }^{89}$

In this way, the Court negated the remedial policies in question while maintaining the theoretical possibility of race classifications being used in remedial laws in the future. This possibility would have a better chance of becoming a reality were the Court to take into account up-to-date social science findings on discrimination. These would make apparent the compelling governmental need to address the adverse effects of unconscious racial stereotypes and negative automatic attitudes.

\section{The Michigan Cases}

In Grutter v. Bollinger and Gratz v. Bollinger, the Court evaluated two University of Michigan admissions policies that took race into consideration in different ways. ${ }^{90}$ In Grutter, the Court upheld a University of Michigan Law School policy, saying that its use of race as one of many factors, combined with the compelling governmental purpose of creating diverse institutions of higher education, satisfied the Equal Protection analysis. In contrast with earlier decisions, the Court found that "not every decision influenced by race is equally objectionable and strict scrutiny is designed to provide a framework for carefully examining the importance

\footnotetext{
${ }^{87}$ Id. at 234.

${ }^{88}$ Adarand at 236-237.

${ }^{89} \mathrm{Id}$.

${ }^{90}$ The University of Michigan Law School admissions policy used a holistic approach while the college's approach assigned numeric values to various characteristics including demographic data such as gender and race.
} 
and the sincerity of the reasons advanced by the governmental decision maker for the use of race in that particular context. ${ }^{\text {} 91}$

In this way, the Court shifted away from its earlier inability to distinguish between invidious and benign racial classifications. Moreover, the Court explicitly held that "effective participation by members of all racial and ethnic groups in the civic life of our Nation is essential if the dream of one Nation, indivisible, is to be realized. ${ }^{, 92}$ This statement, unlike earlier holdings, specifically Washington v. Davis, seemed to recognize that the inclusion of members of multiple racial groups is important to the achievement of excellence. At points, the Court seemed to acknowledge that the appearance of fairness in education is as important as it had previously held race neutrality to be. "It is necessary that the path to leadership be visibly open to talented and qualified individuals of every race and ethnicity. All members of our heterogeneous society must have confidence in the openness and integrity of the educational institutions that provide this training." ${ }^{93}$ The Court cautiously set a time limit of twenty-five years for the continued permissibility of racial classifications in admissions decisions. ${ }^{94}$

In Gratz, the Court rejected the University of Michigan's college admissions policy of adding points for racial minorities in a complicated admissions formula, finding it too inflexible to be permissible under Equal Protection analysis. In reviewing the racial classifications in question, the Court announced that it continues to require strict scrutiny analysis of all racial classifications. ${ }^{95}$ The Court reiterated that the standard was the same, whether or not racial minorities were meant to be benefited or burdened by the classification. ${ }^{96}$ Although the

\footnotetext{
${ }^{91}$ Grutter, 539 U.S. at 327 (2003).

${ }^{92} I d$. at 332.

${ }^{93} \mathrm{Id}$.

${ }^{94} I d$. at 341.

${ }^{95}$ Gratz, 539 U.S. at 270.

${ }^{96} \mathrm{Id}$. at 250.
} 
compelling interest of diversity in higher education was similarly met in Gratz, the Court found the college's admissions formula unable to meet the narrowly tailored requirement. ${ }^{97}$

These most recent Equal Protection decisions offer the clearest understanding of how the Court would have race acknowledged and dealt with in government policies. In upholding the need for consideration of race in order to maintain the diversity of higher education, while rejecting the ability of schools to acknowledge a specific categorization, the Court showed its continued squeamishness about the use of classifications based on race. However, it did evince an understanding that the lack of racial diversity undermines the legitimacy and credibility of educational institutions and is a potential threat to the future of a healthy democracy.

The promotion of a healthy democracy — in particular a diverse, healthy democracy — has been of interest not only to legal scholars, but also to social science scholars, particularly in social psychology. Their work provides an important vantage point from which to evaluate and analyze the assumptions about discrimination and prejudice running through the cases reviewed. But before considering how the Court might be influenced to better understand the psychological operation of discrimination and prejudice, we describe some of the contemporary psychological advances that provide such a perspective.

\section{Psychological Advances in the Understanding of Prejudice and Discrimination}

Social science once shared the Court's understanding that attitudes-especially prejudicial attitudes about racial groups—-were consciously held and, thus, controllable. ${ }^{98}$ However, social psychology has come to recognize a disconnect between explicit expressions of

\footnotetext{
${ }^{97}$ Id. at 280.

${ }^{98}$ Greenwald and Banaji, Implicit Social Cognition: Attitudes, Self-Esteem and Stereotypes, at 4.
} 
attitudes and behavior ${ }^{99}$ which has yet to be recognized in legal conceptualizations of prejudice and discrimination. More significantly, psychologists have been able to document the extent to which implicit attitudes may contradict explicit ones, and the extent to which unconscious attitudes may dictate behavior. ${ }^{100}$ The extent of dissociation and the implications of these dissociations have only recently gained currency and widespread attention. Early theories have been widely accepted and refined to the point of reflecting the new understanding of psychological reality. ${ }^{101}$ The current understanding of the implicit operation of discrimination has been widely validated and accepted into the canon. Theories about the disconnect between explicit beliefs and implicit attitudes have gone in a variety of directions but have produced complementary results. These results, as we will see, largely invalidate the understanding articulated by the Court in contemporary Equal Protection cases. ${ }^{102}$

The four areas in which social science research and theory provide the greatest and most relevant challenge to current Equal Protection analysis are the studies of implicit attitudes, implicit stereotyping, automatic activation, and aversive racism. We outline the historic development of the study of implicit attitudes, beginning with the first study to demonstrate the disconnect between explicit statements and implicit attitudes. Next, we review some of the research related to each of the four theories and their implications for Equal Protection.

\section{A. Implicit Attitudes}

\footnotetext{
${ }^{99}$ McConnell and Leibold, Relations Between the Implicit Association Test, Discriminatory Behavior and Explicit Measures of Racial Attitudes, at 435.

${ }^{100}$ Dovidio and Gaertner, Aversive Racism and Selection Decisions, at 315-316.

101 John F. Dovidio and Samuel L. Gaertner, On the Nature of Contemporary Prejudice: The Causes, Consequences and Challenges of Aversive Racism, in Confronting RACisM: The PROBlem AND THE Response, 4, 3-22 (J. Eberhardt \& S.T. Fiske eds. 1998).

${ }^{102}$ Greenwald and Banaji, Implicit Social Cognition, 4; Patricia G. Devine, Stereotypes and Prejudice: their Automatic and Controlled Components, 56 Journal of Personality and Social Psychology, 5-18 (1989); Nilanjana Dasgupta, Debbie McGhee, Anthony Greenwald and Mahzarin R. Banaji, Automatic Preference for White Americans: Eliminating the Familiarity Explanation, 36 Journal of Experimental Social Psychology 316, (2000); Dovidio and Gaertner, Aversive Racism and Selection Decisions, at 315.
} 
The historic assumption that people know their beliefs and act in accordance with them was challenged by LaPiere in the 1930s in his groundbreaking study of the gulf between people's professed attitudes and their actual behavior. ${ }^{103}$ This study revealed that most hotel owners and restaurant managers throughout the U.S., although they professed that they would not serve a Chinese couple, did in fact serve them when the couple walked into their establishments. ${ }^{104}$ LaPiere traveled throughout the nation with two Chinese companions. During this trip they were refused service in only one of the more than two hundred hotels and restaurants from which they solicited service. Approximately six months later, LaPiere sent each of the establishments from which they had solicited service questionnaires about the business's willingness to serve Chinese customers. Using two questionnaire types, the experimenter received responses from over ninety percent of the establishments saying that they would not "accept members of the Chinese race as guests." 105

This experiment demonstrated that intent to discriminate will not necessarily result in discriminatory behavior. Does the converse hold? Can one discriminate even when one has no explicit intent to do so? Psychologists have long known that observers cannot readily deduce the attitudes of another. Measures of attitudes, such as attitudes towards members of ethnic minority groups, are susceptible to demand and self-presentation effects. ${ }^{106}$ Individuals present a desired image not only to other people but to themselves. Many of the advances in psychological science which we will review begin with the recognition that people will not always report their stereotypical and prejudicial attitudes and, indeed, do not always know the extent to which they hold such attitudes.

\footnotetext{
${ }^{103}$ Richard T. LaPiere, Attitudes v. Actions, 13 Social Forces 230, 230-37 (1934).

${ }^{104}$ Id. at 233.

${ }^{105}$ Id. at 234 .

${ }^{106}$ B. R.Schlenker and M. F. Weigold, 43 Annual Review of Psychology, 133-168.
} 
"Implicit measures in assessing beliefs and attitudes have been introduced to overcome such limits.”107 Implicit attitudes are “introspectively unidentified (or inaccurately identified) traces of past experience that mediate favorable or unfavorable feeling, thought or action toward social objects."108 Implicit measures thus provide means for revealing the true nature of such attitudes and complement explicit attitude measures. ${ }^{109}$ The study of implicit attitudes predates and reaches beyond the Implicit Association Test (IAT), but the IAT is the most common and colloquial measure of implicit attitudes, having been posted on the Web. ${ }^{110}$

"Measures of implicit attitudes can quantify unconscious attitudes and the strength of associations between a given attitude object and the concept 'good' versus the association between the attitude object and the concept 'bad.",111 For example, one of the measures in the IAT measures the response time between faces of Black and White people and words having good or bad connotations. Testers are able to test the response latency and thus determine the relative strength of attitudes held by an individual about a particular group. ${ }^{112}$ Typically, White subjects who report holding no prejudice demonstrate a preference for Whites, seen in the ability to pair White faces significantly more quickly with positively evaluated words and the ability to pair African American faces more quickly with negatively evaluated words. ${ }^{113}$ These results have been shown to be impervious to the familiarity explanation, meaning that they are not

\footnotetext{
${ }^{107}$ Mahzarin R. Banaji, William Cunningham and Kristopher J. Preacher, Implicit Attitude Measures: Consistency, Stability, and Convergent Validity, 12 Psychological Science, 163, 167 (2001).

${ }^{108}$ Greenwald, Implicit Social Cognition: Attitudes, Self-Esteem, and Stereotypes, at 8.

${ }^{109} \mathrm{Id}$. at 163.

${ }^{110}$ Brian Nosek, Wil Cunningham, Mahzarin R. Banaji, and Anthony G. Greenwald, Measuring Implicit Attitudes on the Internet, May 28, 2004 (available at: http://projectimplicit.net/nosek/talk/SPSP.nosek.handout.2000.doc).

${ }^{111}$ McConnell and Leibold, Relations Between the Implicit Association Test, Discriminatory Behavior and Explicit Measures of Racial Attitudes, 435.

${ }_{112}$ Banaji, et. al., Implicit Attitude Measures: Consistency, Stability, and Convergent Validity, at 163.

${ }^{113} \mathrm{Id}$.
} 
dependant on familiarity with images of White faces. ${ }^{114}$ Furthermore, these results have been shown to persist across different racial groups. Approximately $85 \%$ of White people and 50\% of African American people taking this particular test demonstrate a strong automatic preference for Whiteness. ${ }^{115}$

A study using the IAT along with other measures of implicit attitude revealed more significant association between "White" and "good" than between "White" and "bad" and more between "Black” and "bad” than between "Black” and "good.” Research has demonstrated dissociation between explicit and implicit measures of race attitudes. While measures of participants' explicit self attitudes showed non-prejudiced attitudes towards Blacks, measures of implicit measures revealed that they associated Blacks more with negative than with positive attributes. In addition, the overall magnitude of this association has been strong across a variety of testing methodologies, arguing against the potential of a specific tool to determine the outcome. One of the most interesting phenomena that has been repeatedly demonstrated is that subjects “simultaneously self-report nonprejudiced explicit attitudes toward African Americans while showing an implicit difficulty in associating blacks with positive attributes.”116 Recent research has found that explicit attitudes influence actions and reactions when individuals have the opportunity and time for deliberation and consideration. ${ }^{117}$ However, when opportunities for reflection and consideration are not present, because of the immediacy or urgency of the situation, implicit attitudes control. ${ }^{118}$

\footnotetext{
${ }^{114}$ Dasgupta, McGhee, Greenwald and Banaji, Automatic Preference for White Americans: Eliminating the Familiarity Explanation, 316.

${ }^{115}$ Dr. Mahzarin R. Banaji, Ph.D. “Mind Bugs,” Presentation at Sloan School of Management, MIT (April 21, 2004).

${ }^{116} I d$.

${ }^{117} \mathrm{Id}$.

${ }^{118} I d$.
} 
Researchers have used implicit measures in conjunction with more traditional explicit measurements to examine the extent to which explicit attitudes correlate with implicit attitudes. $^{119}$ Studies employing implicit evaluation measures in conjunction with explicit selfreport measures attitudes have, at times, surfaced disparities between the two. ${ }^{120}$ More recently, the IAT has been used in conjunction with behavioral evaluations and has been demonstrated to predict the positivity of interactions between African American experimenters and White subjects. $^{121}$ Social scientists are able to compare IAT results with the behavioral demonstration to determine the extent to which they are correlated. These correlations have significant implications to the extent that they undermine the assumption that beliefs are unrelated to behavior. $^{122}$ The IAT has demonstrably predicted several specific biased social behaviors based on its assessment of implicit measures of attitudes. ${ }^{123}$ Furthermore, the IAT has similarly been linked both to explicitly prejudiced attitudes and discriminatory behavior. ${ }^{124}$

The findings of the IAT and research into implicit attitudes more generally support the proposition, arising from social science research, that individuals typically possess strong preferences for members of their own group, however that group is defined. ${ }^{125}$ These affinities are, however, moderated by the social evaluation of one's group possessed by the larger society. ${ }^{126}$ In the realm of racial discrimination, this means that individuals, although they do not

\footnotetext{
${ }^{119}$ McConnell and Leibold, Relations Between the Implicit Association Test, Discriminatory Behavior and Explicit Measures of Racial Attitudes, 435.

${ }^{120}$ Id. note 9 , at 436 .

${ }^{121} \mathrm{Id}$. at 440 .

${ }^{122} I d$. at 435 .

${ }^{123} \mathrm{Id}$. at 440 .

${ }^{124}$ Id.

${ }^{125}$ Banaji, Ordinary Prejudices, at 9.

${ }^{126} \mathrm{Id}$.
} 
realize it, typically prefer others who share their ethnic or racial identity and that the strength of these preferences is mediated by the collective social value of these groups. ${ }^{127}$

Acknowledging this psychological finding would require the Court to reconsider Justice Powell’s oft-cited statement from Bakke that "preferring members of any one group for no

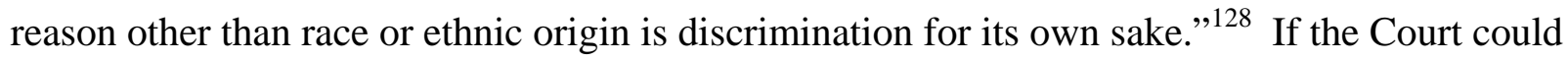
integrate an understanding of the pervasiveness of preferences for the groups one belongs to into its analysis, it might be able to develop an analysis that dealt less with racial classifications per se and more with the impacts on racial and other groups of policies and decisions made by those who are not a member of those groups. This understanding predicts that when attributes typically adhering to White people are more valued than those adhering to African Americans, both groups will treat African Americans less preferentially than they treat White people. This effect has been illustrated quite powerfully in the findings of the IAT and other implicit attitude measures. $^{129}$

After several years and experiment modifications over time, these methodologies have been accepted as both valid and reliable. "With over 75,000 interpretable results, 75\% of White participants and $42 \%$ of Black participants showed pro-White/anti-Black preference.”130 These findings shatter the Court's understanding of prejudice and discrimination as being the result of the malicious intentions of a minority. They suggest that discriminatory attitudes are ubiquitous, often operating without the conscious awareness of the individuals harboring them.

B. Implicit Stereotyping

\footnotetext{
127 Id.

128438 US at 307.

${ }^{129}$ Banaji, "Mind Bugs.” (April 21, 2004).

${ }^{130}$ Nosek, Cunningham, Banaji, and Greenwald, Measuring Implicit Attitudes on the Internet.
} 
Stereotypes, despite their generally negative connotation, are understood within the field of psychology to be as widely held as they are over-general. Stereotypes help individuals organize information, but also lead to assumptions and understandings that tend to reinforce themselves. ${ }^{131}$ Building on the foundations of the implicit attitudes research discussed above, social scientists have explored "the unintended influence of stereotypes on information processing,” more succinctly described as implicit stereotyping. ${ }^{132}$ Other earlier research demonstrated that stereotypes are commonly known, regardless of the compatibility of an individual's beliefs with those stereotypes. ${ }^{133}$ This research connects the powerful findings of implicit attitudes to the earlier research about stereotypes.

Researchers have found that behaviors that contravene common group stereotypes inspire individuals to provide explanations for others' behaviors more often than behaviors that confirm group stereotypes. ${ }^{134}$ Labeled the stereotypic explanatory bias (SEB), this phenomenon has been used to reveal the unintended influence of stereotypes and, more significantly, has been able to predict discriminatory behavior. ${ }^{135}$ In recent experiments, SEB measures correlated highly with behaviors demonstrated in interracial situations. ${ }^{136}$ These results have only been demonstrated in a single study, and therefore require more research, but they may shed light on the subconscious operation of stereotypes in jurisprudence. For example, when evidence related to an individual's academic credentials or job performance fails to conform to a judge’s or jury's implicit racial stereotypes, the judge or members of the jury may unconsciously explain the evidence away. Conversely, evidence that tends to confirm an individual's racial stereotypes may be

\footnotetext{
${ }^{131}$ Sekaquaptewa, Espinoza, Thompson, Vargas and von Hippel, Stereotypic Explanatory Bias: Implicit Stereotyping As A Predictor Of Discrimination, at 75.

${ }^{132} I d .$.

${ }^{133} \mathrm{Id}$.

${ }^{134}$ Id. at 76 .

${ }^{135}$ Id. at 81 .

${ }^{136} I d$.
} 
subconsciously given greater weight. Firm demonstration of such an effect would justify a drastic reconsideration of how the purpose of Equal Protection principles might be best realized. It might suggest a move away from litigation towards arbitration or mediation.

\section{Automatic Activation}

Related to the research on implicit attitudes and implicit stereotypes are findings on the automatic activation of stereotypes. Another significant body of research in social psychology has found that information and knowledge about groups is "automatically activated." ${ }^{\text {"137 Evidence }}$ of automatically activated racialized information has been documented in members of racial minorities and nonmembers alike. ${ }^{138}$

Nonverbal behavior has been found to be particularly subject to the influence of negative implicit attitudes that an individual experiences even despite sincere efforts to behave in a nondiscriminatory manner. ${ }^{139}$ Studies have significantly found that despite the trend for White individuals to demonstrate negativity towards Black individuals, the level of hostility varied. Those who had reported more negativity in their attitudes according to an implicit measure, behaved in a more hostile and generally negative fashion. ${ }^{140}$

These findings directly undermine the assumptions of Equal Protection jurisprudence that discrimination and prejudice are assumed absent unless definitively proven to have motivated the actions of the parties in question. These findings would intimate the opposite assumption: prejudice can be assumed to be present unless it can be definitively proven not to have motivated the party in question. Other social psychological work has taken the general study of automatic

\footnotetext{
137 Banaji, Ordinary Prejudices, at 9.

${ }^{138} \mathrm{Id}$.

${ }^{139}$ Russell H. Fazio, Joni Jackson, Bridget C. Dunton, and Carol J. Williams, Variability in Automatic Activation as an Unobtrusive Measure of Racial Attitudes: A Bona Fide Pipeline?, 69 Journal of Personality and Social Psychology, 1013, 1027 (1995).

${ }^{140}$ Id. at 1019.
} 
prejudice further into the study of social interaction by focusing on the automatic link between social perception and social behavior, ${ }^{141}$ including studies of the linkages between stereotype activation and behaving in line with the content of a stereotype. ${ }^{142}$

D. Aversive Racism

Aversive racism describes the phenomenon whereby self-identified egalitarian Whites act in racist ways when the behavior does not threaten their image of themselves as liberal or egalitarian, and when there is an alternative explanation for their behavior. ${ }^{143}$ In one study, researchers determined that, while explicit measures of racial prejudice have decreased, subtle forms of bias connected to resilient and persistent racialized attitudes and implicit attitudes remain. ${ }^{144}$ The aversive racism perspective clarifies how "many people who explicitly support egalitarian principles and believe themselves to be nonprejudiced also unconsciously harbor negative feelings and beliefs about blacks and other historically disadvantaged groups.”145

To develop this perspective, researchers established tests similar to typical hiring situations where resumes and qualifications are included in the applications of candidates of different races. ${ }^{146}$ The study revealed that when candidates were clearly qualified or clearly unqualified, subjects respectively hired or refused to hire them regardless of race. ${ }^{147}$ However, given discretion—for example when the candidates' qualifications were ambiguous — White subjects clearly demonstrated bias against African American applicants. ${ }^{148}$ In general, research

\footnotetext{
${ }^{141}$ Bargh, J. A., Chen, M., \& Burrows, L. (1996). Automaticity of social behavior: Direct effects of trait construct and stereotype priming on action. Journal of Personality and Social Psychology, 71, 230-244.

${ }^{142}$ Dijksterhuis, A., \& Bargh, J. A. (2001). The perception-behavior expressway: Automatic effects of social perception on social behavior. In M. P. Zanna (Ed.), Advances in experimental social psychology (Vol. 33, pp. 140). San Diego: Academic Press.

${ }^{143}$ Dovidio and Gaertner, Aversive Racism and Selection Decisions, at 315.

${ }^{144} \mathrm{Id}$.

${ }^{145} \mathrm{Id}$.

${ }^{146} \mathrm{Id}$. at 318 .

${ }^{147} \mathrm{Id}$. at 319.

${ }^{148}$ Id. at 317.
} 
on aversive racism has found that conditions of ambiguity are more likely than clear contexts to produce prejudiced reactions. $^{149}$

This theory may help us recognize discrimination in cases when other explanations are available. It suggests that, under such circumstances, White decision makers are more likely to demonstrate bias against African Americans. This becomes particularly significant in relation to situations such as those presented in the Equal Protection cases. Each of these cases presented a discretionary opportunity for governmental actors and, significantly, a discretionary opportunity for the Supreme Court. Although the governmental actors may not have acknowledged the operation of implicit bias or aversive racism, they clearly acknowledged the existence of disparities. The Supreme Court's invalidation of the programs under dispute ensured that these disparities would persist. Could their decisions have been influenced by aversive racism?

The authors of many of the aversive racism studies echo the concern, shared by other employment discrimination experts, that the law is presently ill-suited to handle aversive racism specifically and implicit prejudices more generally. ${ }^{150}$

\section{Incorporating Social Scientific Understandings of Discrimination into Law}

Social science research has found clear evidence that explicit racial prejudice has decreased in recent decades. ${ }^{151}$ Reasons for the decline in explicit discrimination cannot be known definitively, but have been theorized to be a result of social pressure created by the civil rights movement and subsequent civil rights laws and policies. ${ }^{152}$ There is a collective understanding that certain attitudes are morally unacceptable. The evidence from social psychology is that these attitudes nevertheless remain far more common than most would like to

\footnotetext{
${ }^{149}$ Id.; Gaertner and Dovidio, 1981, 1986.

${ }^{150}$ Id at 315.

${ }^{151}$ Dovidio and Gaertner Aversive Racism and Selection Decisions: 1989 and 1999, at 315.

${ }^{152}$ Id. .
} 
acknowledge. This observed resilience of implicit prejudice and discrimination provides a compelling explanation as to the persistence of racial disparities in education, employment, and health. ${ }^{153}$

The importance of these new understandings cannot be overstated. They have literally changed the tenets on which most discrimination and prejudice research is based. There is the potential for an equally enormous shift in the legal understanding of discrimination and prejudice. The disconnect between social science and jurisprudence suggests that legal understandings of discrimination should be reconstructed and suggests arguments that might support this effort.

In particular, because intent is so often absent from prejudice and discrimination, the psychological research evidence weighs against continuing to require evidence of intent to discriminate in evaluating policies and laws with discriminatory impacts. It would also require abandoning the belief that if someone discriminates, he or she is individually prejudiced and malicious and therefore morally responsible for it. This shift in understanding would have powerful implications for Equal Protection jurisprudence.

Although the social science community has overwhelmingly accepted the ideas detailed in this paper, the mainstream public has not been fully included in this intellectual shift. Upon hearing that most people demonstrate prejudiced behavior when using the IAT, individuals often resist believing that they themselves would exhibit such behavior. Such resistance may be accompanied by shame, defensiveness, and justification. It could be that these same negative personal reactions inhibit legal advocates from asserting and judges from adopting these social science understandings into law.

${ }^{153}$ Id. 
These psychological findings may also generate institutional resistance by the very scope of their potential impact. With such a large shift in understanding, the remedial aspects of the law would not be able to keep up. Advocates should therefore take a multifaceted and incremental approach to introducing and incorporating these ideas into law schools, courtrooms, and the mainstream media. The more these ideas are understood by a broad range of people, the easier it will be for the legal community to incorporate them into their arguments and legal theories. Additionally, the use of the mainstream media to disseminate these ideas is bound to foster additional ideas and strategies for undermining unconscious discrimination.

\section{Conclusions}

The increasing acknowledgment of the automatic influence of implicit attitudes on behavior is making it more and more clear that the foundations on which Equal Protection analysis has been based are erroneous. Equal Protection jurisprudence has realized neither the promise of the Fourteenth Amendment nor the ideal of a society where individuals and groups receive the equal protection of the laws. Far from being a sword against the exclusion of racial minorities and a shield for the protection of their rights, the Fourteenth Amendment has become a tool of those who would prefer to act as though the United States were already a colorblind nation.

The Court's holdings demonstrate its discomfort with the historical reality of racial subordination and with the prevailing reality that race consciousness continues to reign and that African Americans and other people of color remain marginalized. Relying on racial classifications, rather than disparate impact or injury, to trigger the Court's examination of programs under strict scrutiny undermines governmental ability to alleviate racial inequities. It 
also illustrates the Court's deeply held but outdated assumptions about how discrimination happens.

The severe impact of these assumptions crystallizes when we look at the number of executions carried out since McCleskey. In that time, 161 African Americans have been executed for killing Whites, while only 11 Whites have been executed for killing African Americans. Moreover, federal prosecutors have sought the death penalty twice as often for African American defendants who killed Whites as for African Americans who killed other African Americans. ${ }^{154}$ In the Court's articulation, these apparent correlations demonstrate the ongoing urgency of the intent requirement in Equal Protection analysis.

The Court's understanding that individuals do know and can control their prejudices and discriminatory behaviors is more fantasy that reality. The social science findings of the last ten years have provided verifiable, reliable, and persuasive evidence that neither of these assumptions holds. Racial discrimination is not an attitude individual's control, but a disease that people unconsciously impose on each other. More profoundly, its devastating effects persist despite carriers insistence that they are not infected. Shifting to a disparate impact standardbased in part on the new understanding that the impact of actions demonstrates intent better than even the most candid attempt to evaluate explicit intent—would acknowledge the injury of racial inequality irrespective of a stated individual or organizational motive. This would more effectively address the disparities in hiring, contractual awards, admissions, and sentencing which not only persist but have worsened without governmental policies to interrupt them.

Although Americans may be more skilled at concealing their explicit racial attitudes than they once were, social science has collected and continues to collect evidence of a society with

\footnotetext{
154 Stephen Wissink, Race and the Big Needle, May 13, 2001 (available at: http://www.alternet.org/story.html?StoryID=10572).
} 
deeply and widely held discriminatory beliefs about groups—-stereotypes that trigger discriminatory behavior. The question remains whether the legal community will acknowledge it. 


\section{Acknowledgements}

The authors thank Jennifer Rothman, Esq., for helpful edits on an early draft of this manuscript. They dedicate this article to Professor Mahzarin Banaji, whose passion and work to advance psychological science for the common good provide intellectual, and inspirational, foundation

for this work. The Center for Public Leadership at the John F. Kennedy School of Government at Harvard University provided financial support towards the preparation of this manuscript. 